\title{
Chemical immobilization of captive Cougars Puma concolor (LINNAEUS, 1771) (CARNIVORA: FELIDAE) USING A COMBINATION OF TILETAMINE-ZOLAZEPAM, KETAMINE AND XYLAZINE
}

\author{
Jesús Lescano ${ }^{1}$, Miryam Quevedo ${ }^{2}$, Luis Baselly ${ }^{3}$, Alberto Crespo ${ }^{4}$ \& Víctor Fernández ${ }^{5}$ \\ ${ }^{1,2}$ Laboratory of Animal Anatomy and Wildlife, ${ }^{4}$ Graduate Studies Unit, ${ }^{5}$ Small Animal Clinic, \\ School of Veterinary Medicine, San Marcos University, 2800 Circunvalación Avenue, Lima 30, Peru \\ ${ }^{3}$ Research Department, Quistococha Zoo, Km 6.3 Iquitos-Nauta Road, Iquitos, Peru \\ 1jlescano@veterinaria-unmsm.edu.pe (corresponding author), ${ }^{2}$ mquevedo@veterinaria-unmsm.edu.pe, \\ ${ }^{3}$ vetjungleluis@gmail.com, ${ }^{4}$ crespoalberto@hotmail.com, ${ }^{5}$ mochefer@hotmail.com
}

\begin{abstract}
Handling of large felids is highly risky, hence immobilization is required for the safety of personnel. Data on the effects of anesthetic drugs used for immobilizing Cougars Puma concolor are scarce. This study describes the anesthetic and cardiorespiratory effects of a combination of tiletamine-zolazepam $(2 \mathrm{mg} / \mathrm{kg})$, ketamine $(1.6 \mathrm{mg} / \mathrm{kg})$ and xylazine $(0.4 \mathrm{mg} / \mathrm{kg})$ in pumas. Five captive adult and clinically healthy Cougars were included in this study. Animals were immobilized by remote injection using blow pipe and darts. The durations of induction, immobilization and recovery periods and their qualities were recorded. Heart rate, respiratory rate, body temperature and blood pressure were recorded at five minute intervals for 25 minutes. Then all animals received $0.125 \mathrm{mg} / \mathrm{kg}$ of yohimbine, intramuscularly administered. Central tendency and dispersal statistics were calculated for each parameter. The duration of the induction period was 10.4 \pm 6.4 minutes and the duration of the recovery period was $83.3 \pm 35.1$ minutes. Induction, immobilization and recovery periods were smooth and adequate anesthetic depth was achieved. The mean heart rate was $122 \pm 10$ beats/minute, mean respiratory rate was $10 \pm 1$ breaths/minute, mean body temperature was $39.1 \pm 0.2{ }^{\circ} \mathrm{C}$ and mean blood pressure was $139 \pm 12 \mathrm{mmHg}$. No statistically significant difference $(p>0.05)$ was observed in vital parameters over the duration of the assessment. The tested anesthetic combination effectively immobilized the cougars included in this study and provided safety for the personnel involved. Though vital signs were not significantly affected, a degree of hypoventilation was observed and respiratory support is recommended when using this anesthetic combination in cougars.
\end{abstract}

Keywords: Anesthesia, carnivores, felids, immobilization, Mountain Lion, zoo animals.

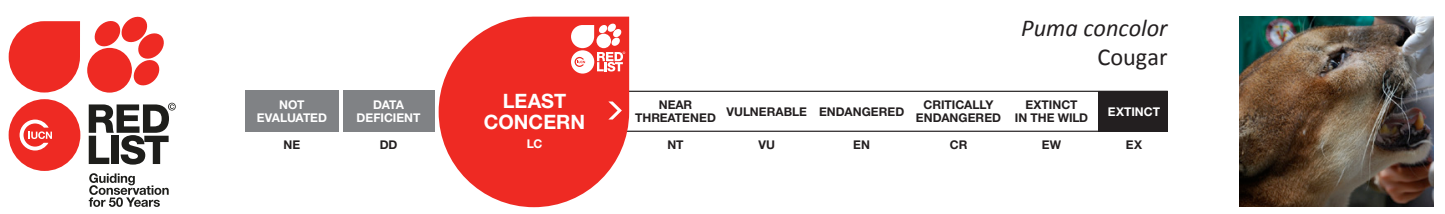

DOI: http://dx.doi.org/10.11609/JoTT.03973.6659-67

Editor: Ulrike Streicher, Wildlife Veterinarian / Wildlife Management Consultant, Eugene, USA.

Date of publication: 26 December 2014 (online \& print)

Manuscript details: Ms \# 03973 | Received 21 March 2014 | Final received 29 November 2014 | Finally accepted 04 December 2014

Citation: Lescano, J., M. Quevedo, L. Baselly, A. Crespo \& V. Fernández (2014). Chemical immobilization of captive Cougars Puma concolor (Linnaeus, 1771) (Carnivora: Felidae) using a combination of tiletamine-zolazepam, ketamine and xylazine. Journal of Threatened Taxa 6(14): 6659-6667; http://dx.doi.org/10.11609/ JoTT.03973.6659-67

Copyright: @ Lescano et al. 2014. Creative Commons Attribution 4.0 International License. JoTT allows unrestricted use of this article in any medium, reproduction and distribution by providing adequate credit to the authors and the source of publication.

Funding: None.

Competing Interest: The authors declare no competing interests.

For Author Details, Author Contribution, Acknowledgements and Spanish Abstract see end of this article.
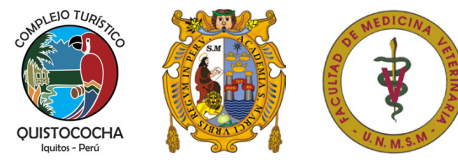


\section{INTRODUCTION}

The Cougar Puma concolor or Mountain Lion is the second largest American felid, only surpassed in size by the Jaguar Panthera onca (Martínez et al. 2010; Hernández-Guzmán et al. 2011). It is distributed from British Columbia in Canada to Tierra del Fuego in Chile, and has the largest distribution range of all neotropical felids and terrestrial mammals in the Western hemisphere (Caso et al. 2008; Macdonald et al. 2010). It inhabits a wide range of ecological zones including deserts, savannahs, tropical rainforests and alpine steppes (Culver et al. 2000; Martínez et al. 2010). The IUCN Red List of Threatened Species lists the species in the category Least Concern, but the population trend is decreasing (Caso et al. 2008; Macdonald et al. 2010).

Large felids are defined as having adult body weight $>20 \mathrm{~kg}$ (Gunkel \& Lafortune 2007) and anatomical characteristics including large sharp claws, specialized teeth for grabbing and tearing, and powerful mandibular muscles (Fowler 2008; Macdonald et al. 2010) which enable them to kill a person (Fowler 2008). For these reasons handling of this group of animals is risky and must be done under appropriate safety measures. Chemical immobilization with anesthetic drugs allows both the safe handling and the minimizing of stress for the animal (Vesal \& Tabatabaei 2007; Fowler 2008; Rockhill et al. 2011).

Ideally, the anesthetic drug combinations used for chemical restraint of wildlife should provide a rapid and smooth induction, good muscular relaxation, effective analgesia, physiological stability during anesthesia, appropriate and predictable duration of the anesthetic effect, should be reversible and have a quick, uncomplicated recovery and minimal adverse effects on hepatic and renal function (Lewandowski et al. 2002; Jacquier et al. 2006). The development of safe immobilization protocols, which are useful when working in situ (e.g., translocation of animals, reintroduction of animals, radiocollaring) and ex situ (e.g., medical control of captive populations) is an important contribution of veterinary medicine to wildlife conservation (Deem 2007; Kock et al. 2007; Nallar 2010; Johansson et al. 2013).

In felids, the use of ketamine or tiletaminezolazepam as a sole anesthetic agent tends to lead to dysphoria, as well as long and rough recovery periods (Pawson \& Forsyth 2008; Moresko et al. 2009). Consequently, the combination of this drug with sedatives and tranquilizers is recommended. Among the anesthetic drug combinations used for immobilization of large felids are: tiletamine-zolazepam/medetomidine (TZM) (Jacquier et al. 2006; Gunkel \& Lafortune 2007; Johansson et al. 2013), ketamine/xylazine/midazolam (KXMid), ketamine/medetomidine/midazolam (KMMid) (Curro et al. 2004; Gunkel \& Lafortune 2007), medetomidine/butorphanol/midazolam (MBMid) (Gunkel \& Lafortune 2007), alphaxalone/alphadolone (AA) (Gunkel \& Lafortune 2007), tiletamine-zolazepam/ ketamine/xylazine (TZKX) (Lewandowski et al. 2002), tiletamine-zolazepam (TZ) (Gunkel \& Lafortune 2007), ketamine/medetomidine (KM) (Tomizawa et al. 1997; Miller et al. 2003; Gunkel \& Lafortune 2007; Rendón et al. 2007) and ketamine/xylazine (KX) (Larsson et al. 2008; Gunkel \& Lafortune 2007; Deka et al. 2012).

Of these drug combinations only the use of TZ, KM and KX have been reported in Puma concolor (Gomes de Oliveira et al. 2001; Gunkel \& Lafortune 2007); however, detailed information on the effects of these anesthetics in Puma concolor is scarce or non-existent. This study aims to assess the efficacy of a tiletaminezolazepam/ketamine/xylazine (TZKX) combination for immobilization of Puma concolor and to describe its cardiorespiratory and anesthetic effects.

\section{MATERIALS AND METHODS}

\section{Animals}

Five adult Cougars of both sexes (four females and one male) were included in this study. All animals were kept at the Quistococha Zoo (Iquitos, Peru). All animals were clinically healthy and the reason for their immobilization was to perform a routine health control. All animals were fasted 24 hours before immobilization.

\section{Chemical restraint}

The following anesthetic drugs were used: tiletamine hydrochloride and zolazepam hydrochloride (Zoletil, Virbac, France), ketamine hydrochloride (Imalgene, Merial, France) and xylazine hydrochloride (Dormi-xyl, Agrovet Market, Peru). These drugs were administered in combination by intramuscular remote injection (in hindlimbs) by means of blowpipe and dart as described by Gunkel \& Lafortune (2007). Target dosages were: $2 \mathrm{mg} / \mathrm{kg}$ of tiletamine-zolazepam, $1.6 \mathrm{mg} / \mathrm{kg}$ of ketamine and $0.4 \mathrm{mg} / \mathrm{kg}$ xylazine. The most recently recorded body weight of each animal was taken as base for the calculation of the drug volume; when a record was missing or the last record was older than one year, the body weight was subjectively estimated based on size and body condition. At the beginning of health control 


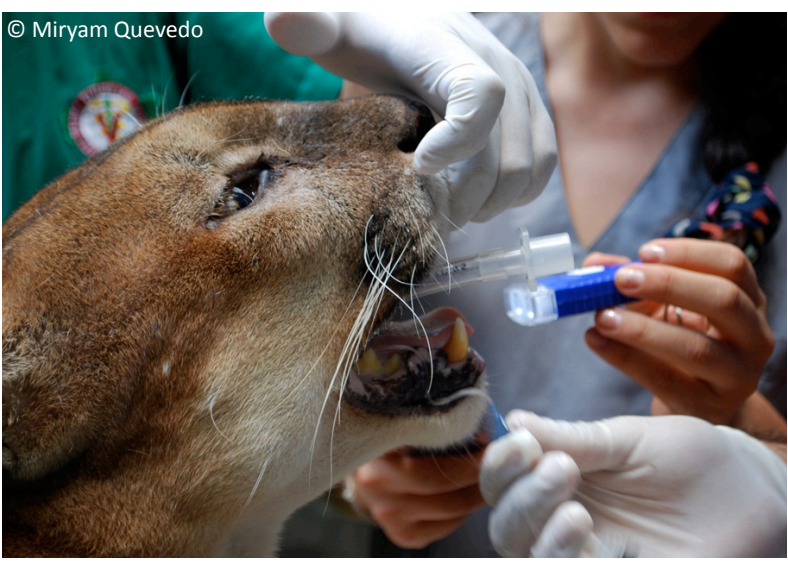

Image 1. Endotracheal tube placement in a Cougar.

procedure each animal was weighed and the actual administered dosage was then calculated.

An endotracheal tube of $8.5 \mathrm{~mm}$ diameter (Rüsch, Teleflex Medical, Germany) was placed in each animal (Image 1) and sodium chloride $0.9 \%$ was administered at a rate of $10 \mathrm{ml} / \mathrm{kg} /$ hour by a $22 \mathrm{G}$ intravenous catheter (Safelet, Nipro Medical, USA) which was placed in the lateral saphenous vein. Once the health control was finished, $0.125 \mathrm{mg} / \mathrm{kg}$ of yohimbine hydrochloride (Yohimbine Vet Up, Richmond, Argentina) was intramuscularly administered.

\section{Data collection}

Anesthetic data were recorded on prepared sheets, following the model of Cracknell (2006). During each immobilization the following data were recorded:

Assessment of length and quality of the anesthetic period: During each immobilization the durations of the following periods were recorded:

- Time to first effect: This was considered to be the time from the dart injection moment to the appearance of ataxia.

- Time to sternal/lateral recumbency: This was considered to be the time from the dart injection to the moment the animal laid down in sternal or lateral recumbency.

- Induction time: This was considered to be the time from the dart injection to the moment the animal was unresponsive to external stimulus.

- Immobilization time: This was considered to be the time from the end of induction time to the moment yohimbine hydrochloride was administered.

- Sternal time: This was considered to be the time from the yohimbine injection to the moment the animal was able to keep itself in sternal recumbency.

- Recovery time: This was considered to be the time
Table 1. Scoring chart for induction, immobilization and recovery periods' quality in Puma concolor (modified from Bakker et al. 2013)

\begin{tabular}{|c|l|l|}
\hline Score & Quality & Characteristics \\
\hline 1 & Good & $\begin{array}{l}\text { Absence of vocalizations, ptyalism, sneezing } \\
\text { or licking. No increased attention to } \\
\text { injection site. Uncoordinated or involuntary } \\
\text { muscular activity is absent. }\end{array}$ \\
\hline 2 & Satisfactory & $\begin{array}{l}\text { Presence of vocalizations, ptyalism, } \\
\text { compulsive licking, sneezing and discomfort } \\
\text { in injection site (finishing at five minutes as } \\
\text { maximum). }\end{array}$ \\
\hline 3 & Unsatisfactory & $\begin{array}{l}\text { Violent struggling or no immobilization. } \\
\text { Severe discomfort (increased attention) at } \\
\text { injection site. Excessive ptyalism, vomit, } \\
\text { compulsive licking, sneezing, involuntary } \\
\text { muscular activity (during more than five } \\
\text { minutes). }\end{array}$ \\
\hline
\end{tabular}

from the yohimbine injection to the moment the animal was able to securely stand and walk.

The quality of the anesthesia was given a numerical score from 1 (good) to 3 (unsatisfactory) as described by Bakker et al. (2013). The scoring criteria are presented in detail in Table 1.

Assessment of anesthetic depth: Muscular relaxation was judged on spontaneous movements, mandibular tone and handling response as well as pedal and palpebral reflexes 15 minutes after successful drug application, according to the scoring scheme described by Lee et al. (2010). The handling response was assessed by lifting a limb with one hand and letting it fall into the other hand. The pedal reflex was assessed by applying intense digital pressure on one digit of the animal. The palpebral reflex was assessed by applying digital pressure on the medial cantus of the eye. Scores ranged from 1 (increased) to 5 (absent) as presented in Table 2. All assessments were performed by the same examiner. Pupil position was descriptively assessed.

Monitoring of cardiorespiratory and thermoregulatory effects: After the induction period was over and full anesthetic effect achieved, heart rate, respiration rate, body temperature, blood pressure, pulse and capillary refill time were monitored and recorded at five minute intervals. Heart rate was measured by thoracic auscultation for one minute. Respiratory rate was measured by direct observation of respiratory movements for one minute. Body temperature was measured with a rectal digital thermometer. Blood pressure was measured using a veterinary vital signs monitor (VS2000V, uBox, China), placing the pressure cuff around the base of the tail (Image 2 ) as suggested by Gunkel \& Lafortune (2007). Pulse was measured by palpation of the sublingual artery and pulse rate 
Table 2. Scoring chart for anesthetic depth in Puma concolor (modified from Lee et al. 2010)

\begin{tabular}{|c|l|l|l|l|l|}
\hline Score & Spontaneous movements & Pedal reflex & Palpebral reflex & Muscle tone \\
\hline 1 & Whole-body movement & Violent limb withdrawal & $\begin{array}{l}\text { Blinking accompanied by } \\
\text { movement of another part } \\
\text { of the body }\end{array}$ & Increased muscle tone & $\begin{array}{l}\text { Limb and another part of the } \\
\text { body movement }\end{array}$ \\
\hline 2 & Movement of one limb & $\begin{array}{l}\text { Immediate weak limb } \\
\text { withdrawal }\end{array}$ & Normal blinking & Normal muscle tone & Rapid limb withdrawal \\
\hline 3 & Facial movements & $\begin{array}{l}\text { Delayed weak limb } \\
\text { withdrawal }\end{array}$ & Immediate weak blinking & Decreased muscle tone & Weak limb withdrawal \\
\hline 4 & $\begin{array}{l}\text { Twitching on fore or hind } \\
\text { limbs }\end{array}$ & $\begin{array}{l}\text { Fingers are flexed or } \\
\text { extended }\end{array}$ & Delayed weak blinking & Minimal muscle tone & $\begin{array}{l}\text { Fingers are flexed or } \\
\text { extended }\end{array}$ \\
\hline 5 & No movement & No movement & No movement & No muscle tone & No response \\
\hline
\end{tabular}

was counted for one minute. Capillary refill time was assessed exerting digital pressure on the oral mucosa and counting the seconds it required to regain color. In addition environmental temperature was recorded with a digital room thermometer.

\section{Statistical Analysis}

The recorded values for heart rate, respiratory rate, body temperature, and blood pressure were evaluated for normal distribution with the Shapiro-Wilk test. When the data were normally distributed the differences within each recorded parameter between the different time points $\left(0^{\prime}, 5^{\prime}, 10^{\prime}, 15^{\prime}, 20^{\prime}, 25^{\prime}\right)$ were assessed using the ANOVA test. When data were not normally distributed the differences were assessed with the Kruskal Wallis test. All statistical analyses were performed with 95\% level of significance and using SPSS software (IBM Corporation, USA).

\section{RESULTS}

The mean age of the immobilized Cougars was 13.0 \pm 3.7 years (range 8-18 years). The mean body weight of the immobilized Cougars was $33.6 \pm 8.1 \mathrm{~kg}$ (range $28-48 \mathrm{~kg}$ ). The actual dosages of administered anesthetic drugs were $2.2 \pm 0.2 \mathrm{mg} / \mathrm{kg}$ of tiletaminezolazepam, $1.8 \pm 0.2 \mathrm{mg} / \mathrm{kg}$ of ketamine, and $0.5 \pm 0.1 \mathrm{mg} /$ $\mathrm{kg}$ of xylazine.

The quality of the induction and immobilization periods was good (mean score $1 \pm 0$ ), whereas the quality of recovery period was good to satisfactory (mean score $1.75 \pm 0.5)$. The achieved anesthetic depth was sufficient to perform health control procedures such as vaccination and biometry. Muscle tone and handling response were absent (mean score $0 \pm 0$ ) in all immobilized Cougars, but pedal and palpebral reflexes remained weakly present in one individual (mean score $0.25 \pm 0.5$ ) and spontaneous movements were observed in another animal (mean

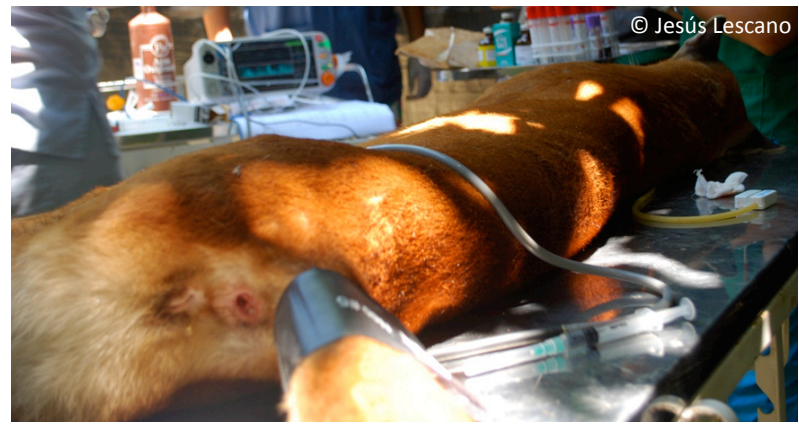

Image 2. Vital signs monitoring in an immobilized Puma concolor. Note the location of the pressure cuff around the base of the tail.

\section{score $0.5 \pm 1)$.}

The mean heart and respiration rates during the entire period of immobilization were $122 \pm 10$ beats/ minute and $10 \pm 1$ breaths/minute. The mean body temperature during the period of immobilization was $39.1 \pm 0.2{ }^{\circ} \mathrm{C}$ with an average environmental temperature of $32 \pm 1.2{ }^{\circ} \mathrm{C}$. Systolic, diastolic and mean blood pressures were $177 \pm 11 \mathrm{~mm} \mathrm{Hg}, 121 \pm 11 \mathrm{~mm} \mathrm{Hg}$ and $139 \pm 12 \mathrm{~mm} \mathrm{Hg}$. The sublingual pulse was perceptible during the period of immobilization and capillary refill time remained below two seconds.

Heart rate, systolic, diastolic and mean blood pressure values were normally distributed ( $p>0.05$ ) Respiratory rate and body temperature were nonnormally distributed $(p<0.05)$. No statistical difference $(p>0.05)$ was observed in heart rate, respiratory rate, body temperature, systolic pressure, diastolic pressure and mean blood pressure over the immobilization period.

The monitored vital signs are presented in Table 3. Heart rate $(H R)$, respiratory rate $(R R)$, body temperature $(T)$, systolic blood pressure (SBP), diastolic blood pressure (DBP) and mean blood pressure (MBP) are shown in the following units respectively: beats per minute (beat/min), breaths per minute (breath/min), degree Celsius $\left({ }^{\circ} \mathrm{C}\right)$ and millimeters of mercury $(\mathrm{mmHg})$ 
Table 3. Vital signs (mean \pm standard deviation) of immobilized Puma concolor by using tiletamine-zolazepam/ketamine/xylazine combination

\begin{tabular}{|c|c|c|c|c|c|c|c|}
\hline \multirow[b]{2}{*}{ Parameter (Unit) } & \multicolumn{6}{|c|}{ Time of assessment (in minutes) } & \multirow[b]{2}{*}{ Mean } \\
\hline & 0 & 5 & 10 & 15 & 20 & 25 & \\
\hline $\mathrm{HR}$ (beat/min) & $123 \pm 7$ & $127 \pm 13$ & $128 \pm 12$ & $126 \pm 8$ & $125 \pm 16$ & $101 \pm 15$ & $122 \pm 10$ \\
\hline RR (breath/min) & $8 \pm 4$ & $9 \pm 2$ & $10 \pm 5$ & $10 \pm 5$ & $12 \pm 9$ & $11 \pm 4$ & $10 \pm 1$ \\
\hline $\mathrm{T}\left({ }^{\circ} \mathrm{C}\right)$ & $39.3 \pm 0.6$ & $39.2 \pm 0.4$ & $39.3 \pm 0.4$ & $39.0 \pm 0.2$ & $39.0 \pm 0.1$ & $38.8 \pm 0.3$ & $39.1 \pm 0.2$ \\
\hline SBP (mmHg) & $197 \pm 22$ & $181 \pm 29$ & $175 \pm 34$ & $175 \pm 39$ & $172 \pm 36$ & $163 \pm 40$ & $177 \pm 11$ \\
\hline $\mathrm{DBP}(\mathrm{mmHg})$ & $141 \pm 12$ & $117 \pm 35$ & $117 \pm 31$ & $121 \pm 33$ & $119 \pm 31$ & $110 \pm 34$ & $121 \pm 11$ \\
\hline $\mathrm{MBP}(\mathrm{mmHg})$ & $159 \pm 13$ & $135 \pm 32$ & $134 \pm 30$ & $150 \pm 19$ & $129 \pm 25$ & $128 \pm 35$ & $139 \pm 12$ \\
\hline
\end{tabular}
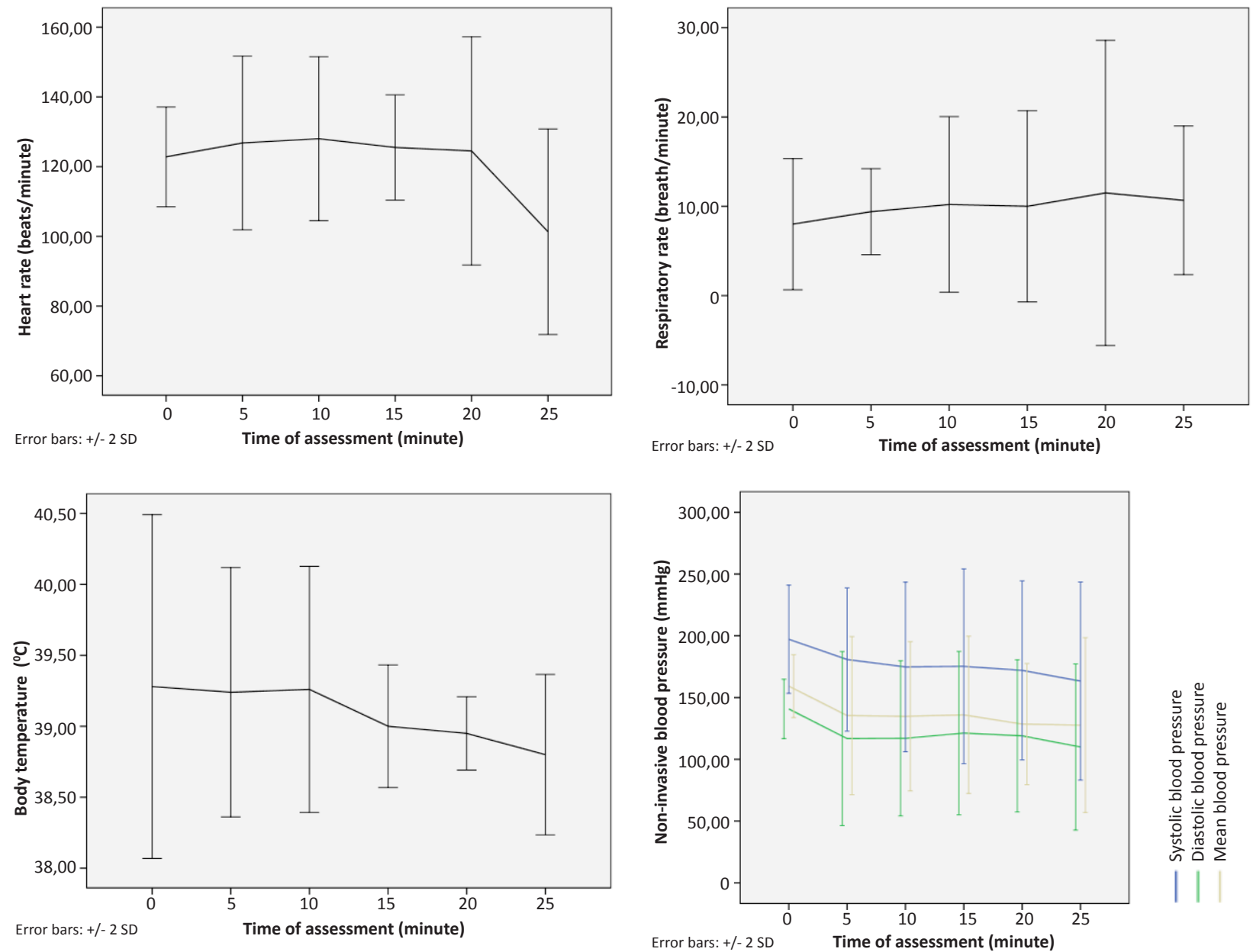

Error bars: +/- 2 SD

Time of assessment (minute)

Error bars: + - 2 SD Time of assessment (minute)

Figure 1. Mean variation of heart rate (beats/minute), respiratory rate (breaths/minute), body temperature $\left({ }^{\circ} \mathrm{C}\right)$ and blood pressure $($ systolic diastolic and mean) (mmHg) of Puma concolor immobilized by using tiletamine-zolazempam/ketamine/xylazine combination

for all blood pressure values.

Trends of the vital signs over the immobilization period are presented in Fig. 1.

Durations of the various stages of anesthesia are presented in Table 4; time to first effect, time to sternal/ lateral recumbency, induction time, immobilization time, sternal time and recovery time.

\section{DISCUSSION}

This article describes for the first time the use of a combination of tiletamine-zolazepam, ketamine and 
Table 4. Duration of anesthetic periods (in minutes) during the immobilization of Cougars Puma concolor by using tiletaminezolazepam/ketamine/xylazine combination.

\begin{tabular}{|l|c|c|}
\hline Period & Mean \pm SD & Range \\
\hline Time to first effect & $1.7 \pm 0.6$ & $1-2.4$ \\
\hline Time to sternal/lateral recumbency & $6.9 \pm 4.8$ & $2.6-12.1$ \\
\hline Induction time & $10.4 \pm 6.4$ & $4.1-19.2$ \\
\hline Immobilization time & $48.3 \pm 12.9$ & $34-59$ \\
\hline Sternal time & $32.5 \pm 17.7$ & $20-45$ \\
\hline Recovery time & $83.3 \pm 35.1$ & $50-120$ \\
\hline
\end{tabular}

xylazine (TZKX) combination for chemical immobilization of Cougars Puma concolor and its effects on physiologic parameters of this species. Furthermore, this article gives the first record of blood pressure in anesthetized Puma concolor.

The mean age of animals included in this study (13.0 \pm 3.7 years) was within the reported lifespan (24 years) for this felid in captivity (Lamberski 2015), but it was higher than the reported lifespan (12 years) for free-ranging Pumas (Currier 1983). Hence, animals included in this study should be considered old, and it should be noted that age might influence the clinical pharmacology of anesthetic drugs (Page \& Maddison 2008).

The dosage of ketamine used in this study for the immobilization of Pumas $(1.8 \mathrm{mg} / \mathrm{kg})$ was slightly lower than the dosage recommended by Gunkel \& Lafortune $(1.9-5.7 \mathrm{mg} / \mathrm{kg})$, who used ketamine in combination with medetomidine. It was considerably lower than the dosage recommended by Gomez de Oliveira et al (2001) $(10 \mathrm{mg} / \mathrm{kg})$, who combined ketamine with xylazine (Gomes de Oliveira et al. 2001).

The dosage of tiletamine-zolazepam used in this study $(2.2 \mathrm{mg} / \mathrm{kg})$ was lower than the dosage recommended $(4-11 \mathrm{mg} / \mathrm{kg})$ when using this drug as the sole agent for the immobilization of Pumas (Gunkel \& Lafortune 2007). And finally the dosage of xylazine used in this study $(0.5 \mathrm{mg} / \mathrm{kg})$ was also lower than the dosage $(1 \mathrm{mg} / \mathrm{kg})$ recommended when combining this drug with ketamine in Pumas (Gomes de Oliveira et al. 2001).

The combination of the drugs in this study enhanced the individual potency of each drug, decreasing their required dosages. A balanced depression of the central nervous system was achieved by combining the effect of a GABA-mimetic drug (zolazepam), an $\alpha 2$ adrenergic receptor agonist (xylazine), and two NMDA receptor blockers (tiletamine and ketamine) (Paddleford 1999). It should be noted that the combined use of ketamine and tiletamine decreases the individual dosages of each drug as both of them belong to the group of phencyclidines and are identical in site of action and effect, being different only in their intensity and duration (Thurmon et al. 1999).

The observed heart rate remained stable between 120-130 beats/min during the first 20minutes of the immobilization period, with a mean of 122 beats/min. At minute 25 of the immobilization period, a slight decrease to 100 beats/min was observed; however, this variation was not statistically significant. Stimulating effects of ketamine and tiletamine on the cardiovascular system might explain the high heart rate observed at the beginning of the immobilization period (Branson 2001; Pawson \& Forsyth 2008). The observed decrease in heart rate thus does not represent bradycardia, as bradycardia in large felids is defined as a heart rate below 40-60 beats/min (Gunkel \& Lafortune 2007).

The mean heart rates observed in this study (122 beats/min) were higher than those observed in Cheetah Acinonyx jubatus immobilized with TZKX (100 beats/ min) (Lewandowski et al. 2002), in Snow Leopards Panthera uncia immobilized with TZM (97 beats/min) (Johansson et al. 2013), in Siberian Tigers Panthera tigris immobilized with $\mathrm{KX}$ ( 82 beats/min) (Larsson et al. 2008), KXMid (105 beats/min) and KMMid (88 beats/ min) (Curro et al. 2004) and in African Lions Panthera leo immobilized with TZM (56 beats/min) (Jacquier et al. 2006) and KX (64 beats/min) (Larsson et al. 2008).

Mean respiratory rates observed in Puma concolor in this study (10 breaths/min) were lower than those observed in Panthera leo immobilized with TZM (17 breaths/min) (Jacquier et al. 2006), in Panthera tigris immobilized with KM (23 breaths/min) (Miller et al. 2003), KXMid (23 breaths/min) and KMMid (19 breaths/ min) (Curro et al. 2004), in Panthera uncia immobilized with TZM (26 breaths/min) (Johansson et al. 2013), and in Acinonyx jubatus immobilized with TZKX (>12 breaths/min). No animal participating in this study developed cyanosis or apnea; however, due to the observed bradypnea, positive pressure ventilation was performed intermittently as supportive measure. Hypoventilation is commonly observed in anesthesia of large felids and it is usually caused by an excessive anesthetic depth (Gunkel \& Lafortune 2007). It should be noted that respiratory rate trended to increase over the immobilization period, which might indicate passage to more superficial anesthetic levels.

The mean body temperature remained about $39^{\circ} \mathrm{C}$ and showed a slight decrease over the immobilization period. The difference between body temperature at the beginning and at the end of immobilization period was about $0.5^{\circ} \mathrm{C}$. Assuming that the body temperature 
range of healthy domestic cats $\left(36-39{ }^{\circ} \mathrm{C}\right)$ (ISIS 2002) provides a valid reference for wild felids (Gunkel \& Lafortune 2007) this decrease appears insignificant; we conclude that the TZKX combination has no clinically important thermoregulatory effects in the Pumas immobilized in this study. The mean body temperature observed in this study was similar to that observed in Acinonyx jubatus immobilized using TZKX $\left(39.1^{\circ} \mathrm{C}\right)$ (Lewandowski et al. 2002). The stability and absence of extreme values in the body temperatures observed in all immobilized Cougars in this study differs from observations in Panthera leo immobilized with KM (Tomizawa et al. 1997) which showed a decrease in body temperature, in Panthera tigris immobilized with KM (Miller et al. 2003) which showed hyperthermia and then decrease of body temperature, and in Panthera tigris altaica immobilized with KXMid (Curro et al. 2004) which showed hyperthermia.

There is little information on physiological blood pressure values in wild felids, but it is assumed that maintaining blood pressure between 60 and $150 \mathrm{mmHg}$ during anesthesia provides adequate tissue perfusion and oxygenation (Gunkel \& Lafortune 2007). The mean blood pressure in this study remained mostly within the mentioned range. The highest mean blood pressure values were observed at the beginning of immobilization, at this stage slightly exceeding the recommended range. Values then decreased, but never fell below the recommended range suggesting hypotension. Overall the variations of systolic, diastolic and mean blood pressure values during the immobilization period were not significant.

The blood pressure values observed in this study were similar to those reported in Panthera tigris altaica immobilized with KXMid or with KMMid (Curro et al. 2004). A similar variation in blood pressure values as observed in our study was reported by Langan et al. (2000), who described initial increase and later decrease of blood pressure in Leptailurus serval immobilized with a ketamine/ medetomidine/ butorphanol combination, suggesting that this variation is caused by the central adrenergic effect of medetomidine.

The observed variation in blood pressure might also be associated with the effect of xylazine, tiletamine or both drugs; $\alpha 2$-adrenergic agonists have a biphasic effect on blood pressure causing and initial hypertension followed by a sustained decrease below the basal value, but not as low as to reach critical levels (hypotension) (Gross 2001; Pawson 2008). Blood pressure of domestic cats immobilized with tiletamine reached their minimum level 30 minutes after injection and returned later to their basal values (Branson 2001).

The dosage of xylazine used in this study was close to the lower limit of the dosage range recommended for wild felids $(0.3-4 \mathrm{mg} / \mathrm{kg})$ when used in combination with other drugs (Stander \& Morkel 1991; Ferreras et al. 1994; Goodrich et al. 2001; Gunkel \& Lafortune 2007; Vesal \& Tabatabaei 2007; Larsson et al. 2008; Rockhill et al. 2011; Deka et al. 2012). The dosage of tiletaminezolazepam used in this study was below the dosages recommended for domestic cats $(6-15.8 \mathrm{mg} / \mathrm{kg})$ when used as a sole drug (Branson 2001; Pawson \& Forsyth 2008) and near the lower limit of the recommended dosage range for large felids (1.6-11 mg/kg) (Gunkel \& Lafortune 2007) when used as a sole drug. As the dosages of xylazine and tiletamine-zolazepam used in our study were both low, their effects on the overall blood pressure profile cannot be determined.

The mean time to the first anesthetic effect (1.7 minutes) was shorter in our study than the mean time to first effects observed in Acinonyx jubatus immobilized with TZKX (4.75 minutes) (Lewandowski et al. 2002). The mean induction time (10.4 minutes) was, however, similar to the mean induction times observed in Acinonyx jubatus immobilized with TZKX (10.2 minutes) (Lewandowski et al. 2002) and in Panthera uncia immobilized with TZM (10 minutes) (Johansson et al. 2013), shorter than the mean induction time observed in Panthera leo immobilized with TZM (14.1minutes) (Jacquier et al. 2006) and longer than mean induction time reported in Panthera tigris immobilized with (8.7minutes) (Miller et al. 2003).

The mean recovery time in this study (83.3minutes) was longer than the mean recovery time observed in Panthera tigris altaica immobilized with KXMid and antagonized with $11 \mathrm{mg} / \mathrm{kg}$ yohimbine (40minutes) or immobilized with KMMid and antagonized with $0.25 \mathrm{mg} / \mathrm{kg}$ atipamezole (21 minutes) (Curro et al. 2004). Tiletamine-zolazepam is known to lead to prolonged recovery times in felids, which has been assumed to be a result of its prolonged presence in the blood when compared to dogs (Branson 2001; Gunkel \& Lafortune 2007). The difference in recovery times is probably due to the use of tiletamine-zolazepam in this study and the absence of this drug in the study of Curro et al. (2004).

The mean recovery time in this study was considerably shorter than the mean recovery time observed in Acinonyx jubatus immobilized with TZKX and antagonized with $0.1-0.2 \mathrm{mg} / \mathrm{kg}$ yohimbine $(251.4$ minutes) (Lewandowski et al. 2002). It should be noted that Lewandowski et al. (2002) did not mention, and therefore probably did not apply, fluid therapy in the 
immobilized Acynonix jubatus; in the present study all immobilized Puma concolor received such therapy. Fluid therapy helps to maintain circulation and improves metabolism of anesthetic drugs (Longley 2008), as it enhances glomerular filtration and accelerates both drug flow in the bloodstream and their excretion (Katzung 2004). Hence, fluid therapy might explain the shorter recovery times observed in our study.

In general, the anesthetic effects of the TZKX combination used in this study to immobilize Puma concolor were similar to the anesthetic effects observed in Acinonyx jubatus immobilized with the same drug combination (Lewandowski et al. 2002). It should be noted that this study specifically assessed the TZKX combination in captive Pumas, and it may not be suitable for free-ranging ones as these might need a higher dose of drugs (Gunkel \& Lafortune 2007).

\section{CONCLUSIONS}

The combination tiletamine-zolazepam/ketamine/ xylazine effectively immobilized captive Puma concolor of both sexes. Blood pressure (systolic, diastolic and mean), body temperature and heart rate remained stable throughout immobilization without significant variations. However a degree of hypoventilation, was observed, and though this was not clinically relevant, we recommend providing respiratory support when using this drug combination in Puma concolor. Also, we recommend applying fluid therapy as our study suggests it shortens recovery time.

\section{REFERENCES}

Bakker, J., J. Uilenreef, E.R.J. Pelt, H.P.M. Brok, E.J. Remarque \& J.A.M. Langermans (2013). Comparison of three different sedative anaesthetic protocols (ketamine, ketamine-medetomidine and alphaxalone) in Common Marmosets (Callithrix jacchus). BMC Veterinary Research 9: 113; http://dx.doi.org/10.1186/1746-61489-113

Branson, K.R. (2001). Injectable anesthetics, pp. 213-267. In: Adams, H.R. (ed.). Veterinary Pharmacology and Therapeutics. $8^{\text {th }}$ Edition. lowa State University Press, Ames, 1201pp.

Caso, A., C. López-González, E. Payán, E. Eizirik, T. de Oliveira, R. Leite-Pitman, M. Kelly, C. Valderrama \& M. Lucherini (2008). Puma concolor. In: IUCN 2013. IUCN Red List of Threatened Species. Version 2013.1. <www.iucnredlist.org>. Downloaded on 15 November 2013.

Cracknell, J. (2006). Anaesthesia Handbook. $1^{\text {st }}$ edition. Zoological Society of London Veterinary Department, 241pp.

Culver, M., W.E. Johnson, J. Pecon-Slattery \& S.J. O’Brien (2000). Genomic ancestry of the American Puma (Puma concolor). The Journal of Heredity 91(3): 186; http://dx.doi.org/10.1093/jhered/91.3.186

Currier M.J.P. (1983). Felis concolor. Mammalian Species 200: 1-7.

Curro, T.G., D. Okeson, D. Zimmerman, D.L. Armstrong \& L.G. Simmons (2004). Xylazine-midazolam-ketamine versus medetomidine- midazolam-ketamine anesthesia in captive Siberian Tigers (Panthera tigris altaica). Journal of Zoo and Wildlife Medicine 35(3): 320-327; http://dx.doi.org/10.1638/03-049

Deem, S.L. (2007). Role of the zoo veterinarian in the conservation of captive and free-ranging wildlife. International Zoo Yearbook 41: 3-11; http://dx.doi.org/10.1111/j.1748-1090.2007.00020.x

Deka, K., V. Athreya, M. Odden \& J. Linnell (2012). Chemical immobilization of Leopard Panthera pardus in the wild for collaring in Maharashtra, India. Journal of the Bombay Natural History Society 109(3): 153-157

Ferreras, P., J.J. Aldama, J.F. Beltrán \& M. Delibes (1994). Immobilization of the endangered Iberian lynx with xylazine- and ketamine- hydrochloride. Journal of Wildlife Diseases 30(1): 65-68; http://dx.doi.org/10.7589/0090-3558-30.1.65

Fowler, M.E. (2008). Chemical restraint, pp. 227-245. In: Fowler, M.E. (ed.). Restraint and Handling of Wild and Domestic Animals. $3^{\text {rd }}$ Edition. Blackwell Publishing, Ames, 470pp.

Gomes de Oliveira, T., E. Eizirik, Jr.P.G. Crawshaw, C.H. Adania, M. da Silva Gomes, W. de Moraes, J.C.R. Silva, N. Moreira, RG. Morato, R.C.R. Paz \& R.N. de Morais (2001). Order Carnivora, Family Felidae (Cats), pp. 291-316. In: Fowler, M.E. \& Z.S. Cubas (eds.). Biology, Medicine, and Surgery of South American wild animals. $1^{\text {st }}$ Edition. lowa State University Press, Ames, 535pp.

Goodrich, J.M., L.L. Kerley, B.O. Schleyer, D.G. Miquelle, K.S. Quigley, Y.N. Smirnov, H.B. Nikolaev \& M.G. Hornocker (2001). Capture and chemical anesthesia of Amur (Siberian) Tigers. Wildlife Society Bulletin 29(2): 533-542.

Gross, M.E. (2001). Tranquilizers, $\alpha 2$-adrenergic agonists, and related agents, pp. 299-342. In: Adams, H.R. (ed.). Veterinary Pharmacology and Therapeutics. $8^{\text {th }}$ Edition. lowa State University Press, Ames, $1201 p p$.

Gunkel, C. \& M. Lafortune (2007). Felids, pp. 443-457. In: West, G., D. Heard \& N. Caulkett (eds.). Zoo Animal and Wildlife Immobilization and Anesthesia. $1^{\text {st }}$ Edition. Blackwell Publishing, Ames, 718pp.

Hernández-Guzmán, A., E. Payán \& O. Monroy-Vilchis (2011). Hábitos alimentarios del Puma concolor (Carnivora: Felidae) en el Parque Nacional Natural Puracé, Colombia. [Diet habits of Puma concolor (Carnivora: Felidae) at the Puracé Natural National Park, Colombia]. International Journal of Tropical Biology 59(3): 1285-1294.

ISIS International Species Information System (2002). Physiological Data Reference Values - Puma Puma concolor. Apple Valley, Minnesota, USA. www.isis.org

Jacquier, M., P. Aarhaug, J.M. Arnemo, H. Bauer \& B. Enriquez (2006). Reversible immobilization of free-ranging African Lions (Panthera leo) with medetomidine-tiletamine-zolazepam and atipamezole. Journal of Wildlife Diseases 42(2): 432-436; http://dx.doi.org/10.7589/00903558-42.2.432

Johansson, Ö., J. Malmsten, C. Mishra, P. Lkhagvajav \& T. McCarthy (2013). Reversible immobilization of free-ranging Snow Leopards (Panthera uncia) with a combination of medetomidine and tiletamine-zolazepam. Journal of Wildlife Diseases 49(2): 338-346; http://dx.doi.org/10.7589/2012-02-049

Katzung, B.G. (2004). Basic and Clinical Pharmacology, $9^{\text {th }}$ Edition. Lange Medical Books, New York, 640pp.

Kock, R.A., P.S. Soorae \& O.B. Mohammed (2007). Role of veterinarians in re-introductions. International Zoo Yearbook 41: 24-27; http:// dx.doi.org/10.1111/j.1748-1090.2007.00013.x

Lamberski, N. (2015). Felids, pp 467-475. In: Miller R.E., M.E. Fowler (eds.). Fowler's Zoo and Wild Animal Medicine. $8^{\text {th }}$ Edition. Elsevier Saunders, St. Louis, 773pp.

Langan, J.N., J. Schumacher, C. Pollock, S.E. Orosz, M.P. Jones \& R.C. Harvey (2000). Cardiopulmonary and anesthetic effects of medetomidine-ketamine-butorphanol and antagonism with atipamezole in Servals (Felis serval). Journal of Zoo and Wildlife Medicine 31(3): 329-334; http://dx.doi.org/10.1638/10427260(2000)031[0329:CAAEOM]2.0.CO;2

Larsson, M.H.M.A., F.M. Coelho, V.M.C. Oliveira, F.L. Yamaki, G.G. Pereira, E.C. Soares, J.D.L. Fedullo, R.C. Pereira \& F.H. Ito (2008). Electrocardiographic parameters of captive Lions (Panthera leo) and 
Tigers (Panthera tigris) immobilized with ketamine plus xylazine. Journal of Zoo and Wildlife Medicine 39(3): 314-319; http://dx.doi. org/10.1638/2007-0028.1

Lewandowski, A.H., C.J. Bonar \& S.E. Evans (2002). Tiletaminezolazepam, ketamine, and xylazine anesthesia of captive Cheetah (Acinonyx jubatus). Journal of Zoo and Wildlife Medicine 33(4): 332336; http://dx.doi.org/10.1638/1042-7260(2002)033[0332:TZKAXA] 2.0.CO;2

Lee, V.K., K.S. Flynt, L.M. Haag \& D.K. Taylor (2010). Comparison of the effects of ketamine, ketamine-medetomidine, and ketaminemidazolam on physiologic parameters and anesthesia-induced stress in Rhesus (Macaca mulatta) and Cynomolgus (Macaca fascicularis) macaques. Journal of the American Association for Laboratory Animal Science 49(1): 57-63.

Longley, L. (2008). Introduction to anaesthesia in exotic species, pp.1-24. In: Longley, L. (ed.). Anaesthesia of Exotic Pets. $1^{\text {st }}$ Edition. Saunders, China, 314pp.

Macdonald, D.W., A.J. Loveridge \& K. Nowell (2010). Dramatis personae: an introduction to the wild felids, pp.3-58. In: Macdonald D.W., A.J. Loveridge (eds.). Biology and Conservation of Wild Felids. $1^{\text {st }}$ Edition. Oxford University Press, Oxford, 761pp

Martínez, J.A., J.C. Rudolf \& D. Queirolo (2010). Puma concolor (Carnivora, Felidae) en Uruguay: Situación local y contexto regional. [Puma concolor (Carnivora, Felidae) in Uruguay: local situation and regional context]. Mastozoología Neotropical 17(1): 153-159.

Miller, M., M. Weber, D. Neiffer, B. Mangold, D. Fontenot \& M. Stetter (2003). Anesthetic induction of captive Tigers (Panthera tigris) using a medetomidine-ketamine combination. Journal of Zoo and Wildlife Medicine 34(3): 307-308; http://dx.doi.org/10.1638/02-036

Moresko, A., S. Larsen \& A.J. Lassiter (2009). Evaluation of the effects of naloxone on recovery time and quality after ketaminemedetomidine-butorphanol anesthesia in Servals (Leptailurus serval). Journal of Zoo and Wildlife Medicine 40(2):289-295; http:// dx.doi.org/10.1638/2008-0078.1

Nallar, R. (2010). Comparación de dos protocolos de inmovilización con ketamina + medetomidina vs. tiletamina/zolazepam + medetomidina en Ocelotes (Leopardus pardalis) de vida silvestre en el Parque Nacional Madidi, Bolivia. [Comparison of two protocols of immobilization with ketamine + medetomidine vs. tiletamine/ zolazepam + medetomidine on free-ranging Ocelot (Leopardus pardalis) in Madidi National Park, Bolivia]. Ecología en Bolivia 45(1): 55-63.

Paddleford, R.R. (1999). Manual of small animal anesthesia. $2^{\text {nd }}$ Edition WB Saunders, St Louis, 372pp.

Page, S.W. \& J.E. Maddison (2008). Principles of clinical pharmacology, pp. 1-26. In: Maddison, J.E., S.W. Page, D.B. Church (eds.). Small Animal Clinical Pharmacology. $2^{\text {nd }}$ Edition. Saunders Elsevier, China, 589pp.

Pawson, P. (2008). Sedatives, pp. 113-125. In: Maddison, J.E., S.W Page, D.B. Church (eds.). Small Animal Clinical Pharmacology. $2^{\text {nd }}$ Edition. Saunders Elsevier, China, 589pp.

Pawson, P. \& S. Forsyth (2008). Anesthetic Agents, pp. 83-112. In: Maddison, J.E., S.W. Page, D.B. Church (eds.). Small Animal Clinica Pharmacology. $2^{\text {nd }}$ Edition. Saunders Elsevier, China, 589pp.

Rendón, E., A. Caso \& D.M. Brousset (2007). Contención química de un Puma (Puma concolor) mediante ketamina-medetimidina, revertida con atipamezol, en Tamaulipas, México. [Chemical restraint of a Cougar (Puma concolor) by means of ketamine-medetomidine reversed with atipmezole, in Tamaulipas, Mexico]. Acta Zoológica Mexicana 23(3): 147-149.

Rockhill, A.P., S.K. Chinnadurao, R.A. Powell \& C.S. DePermo (2011). A comparison of two field chemical immobilization techniques for Bobcats (Lynx rufus). Journal of Zoo and Wildlife Medicine 42(4): 580-585; http://dx.doi.org/10.1638/2010-0152.1

Stander, P.E. \& Pvd.B. Morkel (1991). Field immobilization of lions using disassociative anaesthetics in combination with sedatives. African Journal of Ecology 29: 137-148.

Thurmon, J.C., W.J. Tranquilli \& G.J. Benson (1999). Essentials of Small Animal Anesthesia and Analgesia. 1st Edition. Lippencott, Williams, and Wilkins, Philadelphia, 470pp.

Tomizawa, N., T. Tsujimoto, K. Itoh, T. Ogino, K. Nakamura, S. Hara (1997). Chemical restraint of African Lions (Panthera leo) with medetomidine-ketamine. Journal of Veterinary Medical Science 59(4): 307-310.

Vesal, N. \& A. Tabatabaei (2007). Immobilization and anesthesia of African Lion (Panthera leo) 5 cases. Iranian Journal of Veterinary Surgery 2(3):77-83

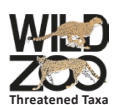

Author Details: JESÚS LESCANO is a veterinary physician currently working as clinical and research assistant at the Laboratory of Animal Anatomy and Wildlife, School of Veterinary Medicine, San Marcos University, Lima, Peru. His main areas of interest are epidemiology of infectious diseases in wildlife and chemical immobilization of free-ranging and captive wild animals. MIRYAM QUEVEDO is a veterinary physician currently working as professor and chief veterinarian at the Wild and Exotic Animal Clinic, Laboratory of Animal Anatomy and Wildlife, School of Veterinary Medicine, San Marcos University, Lima, Peru. Her main areas of interest are conservation education, wildlife health, and exotic small mammals medicine. LUIS BASELLY is a veterinary physician currently working at the Research Department, Quistococha Zoo, Iquitos, Peru. His main areas of interest are zoological medicine and surgery. ALBERTO CRESPO is a veterinary physician currently working as companion animal practitioner. His main areas of interest are ophthalmology and anesthesiology. Víctor FERNÁNDEZ is a veterinary physician currently working as Professor and Director at the Small Animal Clinic, School of Veterinary Medicine, San Marcos University, Lima, Peru. His main areas of interest are pharmacology and toxicology.

Author Contribution: JL performed the study design, chemical immobilizations, literature review and manuscript preparation. MQ performed chemical immobilizations, statistical data analysis, and manuscript preparation. LB performed the logistic support arrangement, anesthetic monitoring, and manuscript review. AC performed the data analysis, manuscript preparation and review. VF performed the logistic support arrangement, and manuscript review.

Acknowledgements: The authors wish to acknowledge Quistococha Zoo for allowing the performance of this study and arranging human resources support. The authors wish to gratefully acknowledge Jessy Alfonso, Alessandra Villena, Grazzia Cruzado and Ángel Góngora for their help during the immobilizations performance. Also the logistic support provided by Dr. Patricia Ríos is acknowledged.

Spanish Resumen: La manipulación de grandes felinos es muy riesgosa, por lo tanto se requiere de inmovilizarlos para garantizar la seguridad del personal. Los datos sobre los efectos de las drogas anestésicas empleadas para inmovilizar pumas (Puma concolor) son escasos. Este estudio describe los efectos cardiorrespiratorios y anestésicos de una combinación de tiletamina-zolazepam $(2 \mathrm{mg} / \mathrm{kg})$, ketamina $(1.6 \mathrm{mg} /$ $\mathrm{kg}$ ) y xilacina $(0.4 \mathrm{mg} / \mathrm{kg})$ en pumas. Se incluyeron cinco pumas adultos y clínicamente sanos. Los animales fueron inmovilizados mediante inyección remota empleando dardos y cerbatana. Se registraron la duración y calidad de los períodos de inducción, inmovilización y recuperación. La frecuencia cardiaca, frecuencia respiratoria, temperatura corporal y presión sanguínea fueron registradas a intervalos de cinco minutos durante 25 minutos. Posteriormente, los animales recibieron $0.125 \mathrm{mg} / \mathrm{kg}$ de yohimbina por vía intramuscular. Se calcularon estadísticos de tendencia central y dispersión para cada parámetro. La duración del período de inducción fue $10.4 \pm 6.4$ minutos y la duración del período de recuperación fue $83.3 \pm 35.1$ minutos. Los períodos de inducción, inmovilización y recuperación fueron tranquilos y se alcanzó profundidad anestésica adecuada. La frecuencia cardíaca promedio fue $122 \pm 10$ latidos/minuto, la frecuencia respiratoria promedio fue $10 \pm 1$ respiraciones/minuto, la temperatura corporal promedio fue $39.1 \pm 0.2{ }^{\circ} \mathrm{C}$ y la presión sanguínea media fue $139 \pm 12 \mathrm{mmHg}$. No se observó diferencia estadísticamente significativa ( $p>0.05$ ) en los parámetros vitales a lo largo del período de evaluación. La combinación anestésica evaluada inmovilizó efectivamente a los pumas incluidos en este estudio y brindó seguridad al personal involucrado. A pesar que los signos vitales no fueron afectados significativamente, se observó un grado de hipoventilación y se recomienda brindar apoyo respiratorio cuando se emplee esta combinación anestésica en pumas. 